\title{
Studi kasus: Pengawasan Kualitas Pangan Hewani melalui Pengujian Kualitas Susu Sapi yang Beredar di Kota Yogyakarta
}

\section{Case Study: Animal Food Quality Control through Moving Cow Milk Quality Testing in Yogyakarta}

\author{
N. S. Anindita* dan D. S. Soyi \\ Departemen Bioteknologi, Fakultas Sains dan Teknologi, Universitas ‘Aisyiyah Yogyakarta \\ *E-mail: nosa.nindita@unisayogya.ac.id
}

(Diterima: 31 Maret 2017; Disetujui: 29 Mei 2017)

\begin{abstract}
ABSTRAK
Pangan sebagai sumber gizi bagi manusia, dapat menjadi sumber penularan penyakit apabila telah tercemar mikroba dan tidak dikelola secara higienis. Keamanan pangan merupakan salah satu masalah penting yang menyangkut pangan. Cemaran mikroba patogen, kimia dan benda-benda lain yang dapat mengganggu, merugikan, dan membahayakan kesehatan manusia menyebabkan pangan menjadi tidak aman untuk dikonsumsi. Pemalsuan susu dengan mencampur susu dengan bahan lain dan cemaran yang dapat mengontaminasi susu menyebabkan perlu adanya manajemen pengawasan dan kontrol kualitas terhadap peredaran susu di masyarakat. Penelitian ini bertujuan untuk mengetahui profil kualitas susu sapi segar yang beredar di Kota Yogyakarta Tahun 2017. Sampel susu diambil dari alur distribusi susu segar di Kota Yogyakarta sebanyak 15 sampel. Teknik pengambilan sampel dilakukan secara langsung pada peternak, agen, pengumpul dan pengecer di Kota Yogyakarta. Analisa data yang digunakan adalah statistik deskriptif. Berdasarkan hasil penelitian, menunjukkan bahwa kualitas susu sapi segar yang beredar di Kota Yogyakarta dalam keadaan baik, aman dan layak untuk dikonsumsi, karena telah sesuai dengan standar kualitas susu segar berdasarkan Standar Nasional Indonesia 01-3141.1-2011.
\end{abstract}

Kata kunci: pangan hewani, keamanan pangan, kontrol kualitas, susu

\begin{abstract}
Food as a source of nutrition can be a source of disease if it was contaminated with microbes and does not managed hygienically. Food safety is one of essential issues related to contamination of pathogenic microbes, chemicals and other objects that can disrupt, harm, and endanger human health. Fabrication of cow milk by mixing it with other ingredients causes lower quality of milk, so supervision to control over the circulation of milk in the community is needed. This study aims to determine the quality of fresh cow's milk profile in the city of Yogyakarta in 2017. Fifteen cow milk samples were taken from distributors channel of fresh milk in Yogyakarta City. Samples was taken directly from farmers, agents, collectors and retailers in Yogyakarta City. The data were analyzed by using descriptive statistic. The result of this research showed that the quality of fresh cow milk in Yogyakarta city is in good condition, safe and feasible to be consumed, based on Indonesian National Standard Number 01-3141.1-2011 about fresh milk quality standard.
\end{abstract}

Keywords: animal food, food safety, quality control, milk

\section{PENDAHULUAN}

Susu merupakan bahan makanan yang istimewa bagi manusia karena kelezatan dan komposisinya yang ideal selain air susu mengandung semua zat yang dibutuhkan oleh tubuh, semua zat makanan yang terkandung didalam air susu dapat diserap oleh darah dan dimanfaatkan oleh tubuh. Menurut Anjarsari (2010), komposisi kimia yang terkandung dalam susu diantaranya lemak $3,8 \%$, protein $3,2 \%$, laktosa $4,7 \%$, abu 0,855 , air $87,25 \%$, serta bahan kering $12,75 \%$. Kandungan gizi yang lengkap menjadi alasan tingginya kebutuhan dan permintaan masyarakat akan susu. Tingginya kebutuhan dan permintaan 
susu di Indonesia masih berbanding terbalik dengan rendahnya pemenuhan susu.

Produksi susu pada 5 tahun terakhir mengalami penurunan rata-rata $1,03 \%$ per tahun atau rata-rata sebesar 847,09 ribu ton. Pada tahun 2017 hingga 2020, Indonesia diperkirakan akan mengalami defisit susu sebesar 71 ribu hingga 103 ribu ton. Pada tahun 2016, tercatat Daerah Istimewa Yogyaakarta sebagai salah satu sentra produksi susu menghasilkan rata-rata 6,22 ribu ton. Konsumsi/kebutuhan susu segar maupun produk turunannya diperkirakan terus meningkat seiring dengan pertumbuhan populasi, pertumbuhan ekonomi, perbaikan tingkat pendidikan, kesadaran gizi dan perubahan gaya hidup baik secara kuantitas maupun kualitas (Agustina, 2016). Kualitas susu dari peternak sapi perah lokal secara umum juga masih di bawah standar dimana hal tersebut berdampak pada rendahnya harga jual ditingkat koperasi maupun industri pengolahan susu (Utami et al., 2014; Usmiati dan Abubakar, 2009).

Menurut Saleh (2004), flavour susu merupakan hasil dari kombinasi komposisi susu (lemak, protein, laktosa, mineral serta vitamin). Penyimpangan flavour susu akibat adanya pencampuran susu dengan bahan lain oleh peternak (air, santan) dan cemaran mikroba, merupakan salah satu indikasi utama adanya kerusakan susu ataupun pencemaran susu yang mengarah pada tidak dapat dimanfaatkannya susu sebagai pangan manusia yang sehat dan menyehatkan. Pemalsuan susu dengan mencampur susu dengan bahan lain dan cemaran yang dapat mengontaminasi susu menyebabkan perlu adanya manajemen pengawasan dan kontrol kualitas terhadap peredaran susu di masyarakat.

Pemeriksaan susu dapat dilakukan secara fisik, kimia dan mikrobiologi. Pemeriksaan secara fisik dapat dilakukan dengan memeriksa warna, rasa dan aroma air susu dengan indera kita, sedangkan pemeriksaan kualitas air susu secara kimia dilakukan dengan menggunakan zat kimia atau reaksi kimia tertentu. Pemeriksaan kualitas susu secara biologis dapat dilakukan dengan mikroskopis, bakteriologis dan biokemis. Pemeriksaan kualitas susu di Indonesia dilakukan tidak hanya terhadap susu, tetapi juga terhadap perusahaan-perusahaan peternakan sapi perah, jadi tempat-tempat produk susu. Pengawasan perusahaan tersebut dibagi dalam pengawasan mengenai peralatan perusahaan (ember, milk can, kandang, dan sapi-sapi) serta pengawasan terhadap pemeliharaannya (Waluyo, 2008).

Pemeriksaan susu terhadap kemungkinan pemalsuan tidak mudah. Hasil pemeriksaan menunjukkan bahwa susu yang diperiksa dibandingkan dengan hasil pemeriksaan susu kandang, yang langsung berasal dari pemerahan sapi. Disamping itu susu setiap hari dapat berbeda, perbedaan ini lebih nyata pada seekor sapi dari pada susu campuran dari berbagai sapi. Perbedaan ini disebabkan karena makanan dan keadaan sapi-sapinya sendiri. Pemalsuan dapat dilakukan sedemikian rupa sehingga susu tidak memperlihatkan adanya penyingkiran susunannya. Berbagai macam bahan yang sering digunakan dalam proses pemalsuan susu diantaranya: air, skim milk, santan, air kelapa, air beras atau tajin, susu kambing, susu kaleng atau penambahan gula dan tepung (Murti, 2010).

Beberapa indikator terkait pemalsuan susu yang harus diperhatikan diantaranya yaitu: (1) Susu dengan BJ yang rendah harus diawasi misalnya lebih rendah dari 1,0280 , walaupun tidak semuanya dipalsukan dengan penambahan air; (2) Bila disamping itu didapatkan kadar lemak rendah, maka kemungkinan pemalsuan lebih besar; (3) Dalam hal itu \% lemak dalam bahan kering dapat dihitung. Bila kadar lemak dalam bahan kering lebih rendah dari $2,5 \%$, maka susu harus dikatakan abnormal; (4) Pemalsuan dengan air dapat dibuktikan selanjutnya, bila titik beku atau angka refraksi susu diperiksa. Susu di Indonesia mempunyai titik beku normal diantara $0^{\circ} \mathrm{C}$ dan $-0,520^{\circ} \mathrm{C}$, sedangkan angka refraksi minimal harus 34 (Milk Codex). 
Perubahan-perubahan susu dapat pula terjadi karena perubahan makanan yang diberikan dan (5) Bila B.J susu normal, akan tetapi kadar lemaknya rendah, maka biasanya hal ini disebabkan oleh pengambilan kepala susu (krim), juga \% lemak di dalam bahan kering sangat rendah. Dalam hal ini penetapan titik beku susu sangat penting (Murti, 2010).

Kontrol kualitas sendiri merupakan hal yang penting yang harus dilakukan secara rutin untuk menjaga kualitas susu segar, sehingga susu segar yang beredar di Kota Yogyakarta sesuai standar kualitas yang baik dan aman untuk dikonsumsi masyarakat tanpa menimbulkan gangguan kesehatan bagi konsumen. Penelitian ini bertujuan untuk mengetahui kualitas susu sapi segar pada level peternak, agen/pengumpul dan pengecer yang terdapat di Kota Yogyakarta ditinjau dari uji organoleptik, fisik, kimia dan mikrobiologis susu. Pentingnya pengawasan dan jaminan mutu terhadap kualitas susu segar, maka peneliti merasa perlu melakukan penelitian terkait pengujian kualitas susu sapi segar yang beredar di Kota Yogyakarta.

\section{METODE}

Kegiatan penelitian ini dilakukan di Laboratorium Teknologi dan Pengolahan Susu Telur Fakultas Peternakan, Universitas Gadjah Mada, Yogyakarta selama 6 bulan. Wilayah dari penelitian ini adalah distributor susu yang melakukan peredaran susu sapi segar di Kota Yogyakarta, sebanyak 20 sampel meliputi peternak (baik dari wilayah Yogyakarta maupun dari luar Yogyakarta), pengecer dan agen. Peternak dan Agen yang digunakan sebagai sampel merupakan agen yang paling banyak menyuplai kebutuhan susu sapi segar di Kota Yogyakarta. Teknik pengambilan sampel dilakukan secara langsung dan segera dilakukan pengujian di laboratorium. Sampling dilakukan pada setiap alur pemasaran susu dengan sampel susu yang diambil sebanyak $500 \mathrm{ml}$.

Pengambilan sampel susu di ambil dengan cara mengaduk susu terlebih dahulu dengan alat pengaduk sampai ke dasar hingga rata. Peralatan pemeriksaan sampel susu yang digunakan saat pengambilan dalam keadaan kering, bersih dan tidak berlemak yaitu alat pengaduk tahan karat dan kantong plastik (high density polyetilena) yang tidak bereaksi dengan susu. Sampel susu kemudian dimasukkan dalam termos yang telah diisi dengan es sebagai pendingin, hal ini bertujuan untuk menjaga kualitas susu (keadaan dan susunan) khususnya kualitas mikrobia dan nilai nutrisi selama transportasi dari tempat pengambilan sampel hingga tempat pengujian.

Kegiatan yang dilakukan selama penelitian ini meliputi pengambilan sampel susu segar yang beredar di wilayah Kota Yogyakarta, uji kualitas susu di laboratorium dan pengumpulan data. Pengumpulan data dilakukan dengan pengamatan secara langsung, wawancara dengan peternak, pengumpul, agen dan loper atau pengecer susu. Pengawasan susu segar meliputi kontrol kualitas fisik, kimia dan mikrobiologis susu segar yang berhubungan dengan pengawasan peredaran susu segar di Kota Yogyakarta. Metode pengujian kualitas susu segar mengacu pada Diastari dan Agustina (2013), Yusuf (2010) dan Soeparno et al. (2011).

Pengujian kualitas organoleptik mengacu pada metode Diastari dan Agustina (2013), kualitas fisik dan sedimentasi susu terhadap kotoran dan benda asing dilakukan menggunakan metode Yusuf (2010). Sedangkan pengujian kualitas kimia dan mikrobiologis susu menggunakan metode Soeparno et al. (2011). Pengambilan sampel diulang 3 kali dan data hasil penelitian dianalisis secara deskriptif.

\section{HASIL DAN PEMBAHASAN}

\section{Pemantauan dan Pengambilan Sampel Susu}

Pemantauan dan pengambilan sampel di lakukan secara langsung melalui alur pemasaran susu di lakukan pagi hari yaitu 


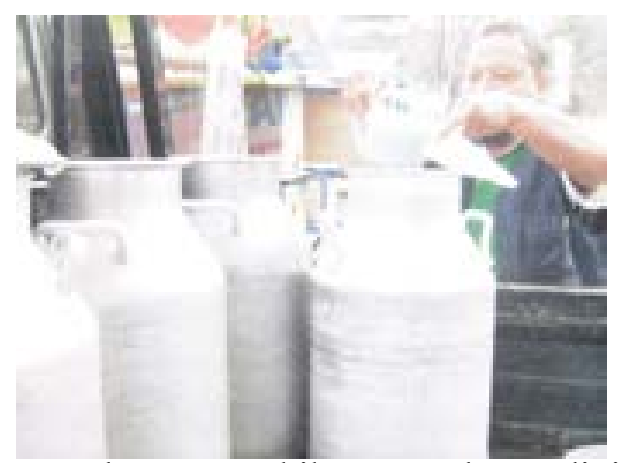

Gambar 1. Pemantauan dan pengambilan sampel susu di tingkat pengumpul.

antara pukul 06.00 sampai pukul 08.30 WIB, hal tersebut dilakukan karena proses pemerahan dan pendistribusian susu dimulai di pagi hari. Waktu ataupun jadwal untuk sampling bersifat acak dan jadwal tidak tentu karena merupakan sidak. Rata-rata sampling susu yang dilakukan perminggu sebanyak 2 sampai 3 kali sampling. Frekuensi sampling susu yang paling sering dilakukan secara berurutan adalah susu yang berasal dari daerah Sleman, Kota Yogyakarta dan Bantul, sedangkan frekuensi sampling susu yang paling jarang dilakukan adalah susu yang berasal dari daerah Kulon Progo, karena peternak Kulon Progo yang menyetorkan susu atau menyuplai susu ke Kota Yogyakarta hanya satu orang. Pengujian sampel bertujuan untuk menjaga kualitas susu yang dijual, karena dikhawatirkan terjadi kecurangan yaitu mencampur susu dengan bahan pengawet (garam), santan, air dan urea. Kontrol kualitas susu yang dilakukan yaitu meliputi uji organoleptik, fisik, kimia dan mikrobiologis. Peternak di Kota Yogyakarta sejumlah 7 peternak dengan produksi susu sekitar 6 sampai 24 1/hari. Peternak yang berasal dari luar Kota Yogyakarta berjumlah 5 peternak dengan produksi susu sekitar 10 sampai 60 1/hari.

Peredaran susu di Kota Yogyakarta dapat melalui agen dan pengecer. Pemantauan dan pengambilan sampel di tingkat pengecer dan agen dilakukan antara pukul 07.00 sampai pukul 09.00 WIB. Prosedur yang dilakukan sama dengan di tingkat produsen susu. Jumlah pengecer dan agen yang ada di Kota Yogyakarta sebanyak 10 dengan penjualan susu sekitar 20 sampai 650 1/hari. Peredaran susu di Kota Yogyakarta juga dapat melalui pengumpul susu (Gambar 1).

Sampel susu yang diambil dari peternak, pengumpul, agen dan pengecer kemudian dilakukan uji kualitas di Laboratorium Teknologi dan Pengolahan Susu Telur. Fakultas Peternakan, UGM. Selama sampling, susu yang berasal dari daerah Sleman mempunyai kualitas susu yang bagus.

\section{Pengujian Kualitas Susu Sapi}

Susu disukai mahluk hidup, termasuk bakteri karena selain komposisi gizinya yang lengkap, juga karena $\mathrm{pH}$ susu mendekati $\mathrm{pH}$ normal, yaitu 6,6 sampai 6,8 dan kadar air yang tinggi, yaitu 87 sampai $88 \%$ (Murti, 2010). Susu di masyarakat dipakai sebagai bahan pangan untuk pemenuhan gizi, sehingga jaminan atas kualitas susu harus lebih diperhatikan, seperti halnya dalam proses pemerahan sapi hingga sampai ke tangan konsumen yang dalam hal ini adalah masyarakat itu sendiri.

\section{Kualitas organoleptik susu sapi}

Pengujian organoleptik merupakan salah satu cara mendasar dan pertama kali dilakukan untuk mengetahui kualitas dari bahan tersebut. Pengujian organoleptik merupakan pengujian yang subyektif, akan tetapi pengujian ini memiliki peran yang penting. Pengujian ini terdiri dari rasa, aroma dan warna. Rasa dan aroma dapat bersinergi membentuk citarasa. Citarasa susu sapi dipengaruhi beberapa faktor. Berdasarkan hasil pengujian, sampel susu selama penelitian dalam kondisi aman dan layak 
Tabel 1. Hasil pengujian kualitas susu sapi yang beredar di kota Yogyakarta.

\begin{tabular}{lcccc}
\hline \multirow{2}{*}{ Parameter Uji } & \multicolumn{3}{c}{ Bulan Pengujian } & \multirow{2}{*}{ Rerata } \\
\cline { 2 - 4 } & Jan 17 & Feb 17 & Mar 17 & \\
\hline Organoleptik & Tap & Tap & Tap & Tap \\
Derajat Asam ( $\left.{ }^{\circ} \mathrm{SH}\right)$ & $6,8 \pm 0,1$ & $6,5 \pm 0,1$ & $6,6 \pm 0,1$ & $6,63 \pm 0,1$ \\
Alkohol & - & - & - & - \\
Didih & - & - & - & - \\
Lemak (\%) & $3,4 \pm 0,2$ & $3,5 \pm 0,2$ & $3,4 \pm 0,2$ & $3,4 \pm 0,2$ \\
BJ, pada suhu 27,5 ${ }^{\circ} \mathrm{C}$ & $1,0265 \pm 0,0007$ & $1,0245 \pm 0,0022$ & $1,0269 \pm, 0023$ & $1,0259 \pm 0,0007$ \\
BKTL (\%) & $7,96 \pm 0,21$ & $7,29 \pm 0,19$ & $7,89 \pm 0,21$ & $7,71 \pm 0,21$ \\
MBRT (jam) & $2,89 \pm 0,35$ & $2,81 \pm 0,23$ & $3,00 \pm 0,26$ & $2,90 \pm 0,06$ \\
Sedimentasi & - & - & - & - \\
Total bakteri (cfu/ml) & $1,1 \pm 0,5 \times 10^{4}$ & $4,8 \pm 1,5 \times 10^{4}$ & $9,7 \pm 5,1 \times 10^{4}$ & $5,2 \pm 2,5 \times 10^{4}$ \\
\hline
\end{tabular}

untuk dikonsumsi. Hasil uji organoleptik yaitu untuk warna susu putih kekuningan, memiliki aroma khas susu dan rasa susu normal yaitu gurih dan manis khas susu, dari hasil tersebut menunjukkan bahwa susu tidak mengalami perubahan. Hasil pengujian tersebut telah memenuhi persyaratan sebagai susu layak konsumsi sesuai SNI 01-3141.12011. Menurut Badan Standar Nasional Indonesia (2011), bahwa susu segar dikatakan masih baik apabila warna, aroma dan rasa tidak mengalami perubahan. Faktor-faktor yang mempengaruhi citarasa susu antara lain adalah penyerapan bau, bahan pakan ternak, kondisi ternak, pengaruh sinar matahari dan penambahan bahan asing.

Hasil tersebut diperkuat dengan beberapa pendapat dari beberapa peneliti. Pada waktu susu berada di dalam ambing ternak yang sehat atau beberapa saat setelah keluar, susu merupakan suatu bahan murni, higienis, bernilai gizi tinggi, mengandung sedikit bakteri yang berasal dari ambing, bau, rasa tidak berubah dan tidak berbahaya untuk diminum (Sanam et al., 2014). Ciri khas susu yang baik dan normal adalah susu tersebut terdiri dari konversi warna kolostrum yang berwarna kuning dengan warna air susu yaitu putih, jadi susu normal itu berwarna putih kekuning-kuningan. Kriteria lainnya adalah jika berwarna biru maka susu telah tercampur air, jika berwarna kuning maka susu mengandung karoten, dan jika berwarna merah maka susu tercampur dengan darah (Yusuf, 2010).

Pengujian dengan menggunakan indra penciuman dilakukan dengan membaui susu tersebut, apabila baunya normal maka susu berkualitas baik. Aroma khas tersebut ditimbulkan karena adanya asam-asam lemak. Aroma susu bisa berubah apabila ada pertumbuhan mikroba di dalam susu (susu menjadi asam) atau aroma lainnya (bukan aroma susu) akibat senyawa aroma ini diserap oleh lemak susu (Lukman, 2009). Aroma pakan dan kotoran didekat wadah susu juga mudah mempengaruhi aroma susu. Rasa manis dari susu diakibatkan karena kandungan karbohidrat (laktosa) yang cukup tinggi.

\section{Kualitas fisik susu sapi}

Kebersihan merupakan faktor penting dalam menjaga kualitas susu. Lingkungan yang tidak bersih mendukung pertumbuhan bakteri di dalam susu, sehingga mempercepat kerusakan pada susu. Sampel susu penelitian untuk uji sedimentasi kotoran dan benda asing dalam kondisi bersih dan layak untuk dikonsumsi. Selanjutnya sampel susu dilakukan pengujian terhadap berat jenis. Tujuan dilakukannya uji berat jenis adalah untuk mengetahui jika terjadi penyimpangan terhadap susu segar dalam hubungannya dengan penambahan air. Rerata berat jenis susu segar selama penelitian adalah 1,0259 $\pm 0,0007$. Apabila dibandingkan pada SNI 
(2011) nilai berat jenis selama penelitian masih kurang dimana berat jenis untuk susu segar pada suhu $27,5{ }^{\circ} \mathrm{C}$ minimal $1,0280 \mathrm{~g} /$ ml. Nilai BJ yang kurang tersebut dapat disebabkan oleh beberapa hal diantaranya perubahan kondisi lemak dan adanya gas yang timbul di dalam air susu atau bisa juga susu dibiarkan dalam keadaan terbuka (tanpa penutup) sehingga uap air akan masuk ke dalam susu. Kandungan yang terlarut didalam susu dimana semakin banyak senyawa yang terdapat dalam susu maka berat jenis susu akan meningkat.

Selanjutnya sampel susu dilakukan pengujian alkohol dan uji didih, berdasarkan hasil pengujian sampel susu selama penelitian menunjukkan bahwa tanda negatif tidak ada gumpalan terlihat pada dinding tabung reaksi, maka susu masih dalam keadaan baik. Hasil pengujian tersebut sesuai dengan SNI (2011) bahwa susu segar dengan kualitas baik ketika dilakukan pengujian alcohol $70 \%$ dan uji didih menunjukkan tanda negatif. Hasil pengujian yang sama juga diperoleh Nababan et al. (2014), yang melakukan pengujian terhadap kualitas susu segar di Kota Denpasar pada tingkat produsen. Pengujian dikatakan positif, ditandai adanya gumpalan yang menempel di dinding tabung reaksi, yaitu partikelpartikel kasar yang melekat pada dinding tabung (Suardana dan Swacita, 2009). Hal ini disebabkan karena kestabilan kaseinnya berkurang sehingga terjadi koagulasi kasein dan akan mengakibatkan penggumpalan susu. Pecahnya susu menyebabkan kualitas susu rendah sehingga tidak layak dikonsumsi karena adanya kemungkinan bahwa kadar asam yang terkandung dalam susu tinggi (Sutrisna et al., 2014).

Susu yang tidak benar dapat menyebabkan daya simpan susu menjadi singkat (Zakaria et al., 2011). Kualitas fisik dan kimia susu sapi segar dipengaruhi oleh faktor bangsa sapi perah, pakan, system pemberian pakan, frekuensi pemerahan, metode pemerahan, perubahan musim dan periode laktasi (Lingathurai et al., 2009). Bakteri pembusuk asam laktat adalah
Steptococcus thermophillus, Lactobacillus laktis, dan Lactobacillus thermophillus (Umar et al., 2014). Menurut Buckle et al. (2010) aktivitas bakteri dalam susu akan menurunkan $\mathrm{pH}$ secara nyata. Menurunnya $\mathrm{pH}$ susu menyebabkan protein susu seperti kasein berada pada titik isoelektriknya sehingga protein tersebut akan menggumpal. Kenaikan $\mathrm{pH}$ susu juga dapat menjadi tanda adanya mastitis pada sapi.

\section{Kualitas kimia susu sapi}

Lemak merupakan sumber utama nutrisi yang ada dalam susu. Pada umumnya komposisi susu sapi terdiri atas air dan bahan kering dimana salah satunya adalah lemak. Lemak susu merupakan komponen yang sama pentingnya seperti protein maupun karbohidrat. Tinggi rendahnya kandungan lemak pada susu sapi sangat mempengaruhi harga jual dari susu tersebut. Pengujian kadar lemak susu ini menggunakan Metode Gerber. Kadar lemak susu sapi daribulan Januari hingga Maret 2017 tidak menunjukkan perubahan yang terlalu signifikan dan bahkan cenderung stabil, dengan rerata kadar lemak sebesar $3,40 \pm 0,20 \%$. SNI (2011) mensyaratkan nilai kadar lemak minimum pada susu sapi sebesar $3,0 \%$, berdasarkan standar tersebut susu sapi yang beredar di Kota Yogyakarta memiliki kadar lemak yang sesuai.

Kandungan lemak hasil penelitian jauh lebih besar apabila dibandingkan hasil penelitian yang telah dilakukan Mirdhayati et al. (2008) bahwa kadar lemak susu segar di UPT Ruminansia Besar Riau sebesar 1,6\% di mana kadar lemak susu dipengaruhi oleh pakan karena sebagian besar dari komponen susu disintesis dalam ambing dari substrat sederhana yang berasal dari pakan. Zurriyati et al. (2011), jenis pakan yang diberikan pada sapi juga berepengaruh terhadap tinggi rendahnya kandungan lemak dalam susu yang dihasilkan. Pakan hijauan merupakan sumber serat, semakin banyak produksi asetat, semakin banyak sintesis asam lemak yang kemudian menghasilkan peningkatan kadar lemak susu. Kandungan lemak dalam susu adalah komponen terpenting disamping 
protein yang mempengaruhi harga jual susu

Susu sapi yang beredar di Kota Yogyakarta juga dilakukan pengujian Berat kering Tanpa Lemak (BKTL/SNF). Pengujian ini bertujuan untuk mengetahui kadar total padatan yang bukan lemak pada susu, sehingga kualitas susu segar dapat ditentukan. Padatan non lemak dalam susu yang terukur dalam pengujian ini merupakan padatan berupa laktosa, protein, vitamin, mineral dan padatan-padatan lain. Selama bulan Januari hingga Maret 2017 kadar BKTL tidak terjadi perubahan yang signifikan yaitu berada pada kisaran 7,71 $\pm 0,21 \%$. Rerata BKTL pada susu-susu sapi di Kota Yogyakarta telah sesuai dibandingkan dengan SNI (2011) yang menyebutkan nilai BKTL minimum sebesar $7,8 \%$.

\section{Kualitas mikrobiologi susu sapi}

Selama pengujian sampel, susu segar yang beredar di Kota Yogyakarta selama bulan Januari hingga Maret 2017 rata-rata menunjukkan susu masih dalam keadaan yang baik dan layak dikonsumsi dengan hasil uji MBRT adalah 2,90 $\pm 0,06$ jam. Menurut SNI No. 01-3141.1-2011, angka reduktase pada susu segar adalah 2 sampai 5 jam. Uji MBRT ini berhubungan dengan jumlah bakteri yang berada dalam susu segar. Kontrol kualitas mikrobiologis yaitu uji MBRT mempunyai korelasi dengan jumlah bakteri, sehingga susu dapat diklasifikasikan menjadi beberapa mutu.

Pengujian ini berkaitan dengan jumlah bakteri dalam susu segar, dimana bakteri mempunyai kemampuan untuk menghilangkan warna biru yang berasal dari methylene. Hal ini di sebabkan kemampuan bakteri didalam susu untuk tumbuh dan menggunakan oksigen yang terlarut sehingga menyebabkan penurunan kekuatan oksidasireduksi dari campuran tersebut. Akibatnya metylen blue akan direduksi menjadi warna putih. Semakin. Semakin banyak bakteri dalam susu, maka aktivitasnya akan membuat warna biru dari methylene cepat hilang. Hasil pengujian dari uji MBRT berkorelasi dengan total bakteri ini, dimana waktu reduksi (jam) yang lama menunjukkan jumlah bakteri yang sedikit, untuk sampel susu dengan rataan MBRT sebesar 2,90 $\pm 0,06$ jam memiliki perkiraan jumlah bakteri dalam jumlah satuan ribuan sehingga tidak sampai dalam hitungan jutaan. Akan tetapi dari bulan Januari hingga Maret 2017 secara berurutan masing-masing yaitu $1,1 \pm 0,5 \times 104 ; 4,8 \pm 1,5 \times 104$; dan $9,7 \pm 5,1 \times 104 \mathrm{cfu} / \mathrm{ml}$ (Tabel 1) mengalami kenaikan.

Menurut Nandy dan Vanketesh (2010), melakukan studi bahwa waktu reduksi (jam) yang lama menunjukkan jumlah bakteri (cfu/ ml) yang sedikit, sedangkan waktu reduksi (jam) yang cepat menunjukkan jumlah bakteri (cfu/ml) yang banyak. Semakin cepat waktu $(<2$ jam $)$ yang dibutuhkan untuk menetralkan warna biriu, semakin buruk kualitas mikrobiologis susu segar. Akan tetapi berdasarkan hasil pengujian, terdapat beberapa hasil pengujian menunjukkan korelasi yang ada berkebalikan dari hasil pengujian susu segar. Sehingga pengujian mikrobiologis bervariasi, lamanya hasil MBRT ini dapat dipengaruhi oleh keadaan lingkungan yang kurang bersih dapat mempermudah terjadinya pencemaran. Budyanto dan Usmiati (2008) menjelaskan bahwa keamanan pangan susu ditentukan pada saat penanganan baik persiapan dan pemerahan susu, pengolahan produk menjadi bahan pangan, serta dalam rantai pemasaran. Penanganan susu secara higienis akan meningkatkan mutu dan keamanan susu. Penanganan susu yang kurang higienis mengakibatkan rendahnya mutu dan keamanan susu sehingga menjadi penyebab utama kerugian dan mengurangi pendapatan peternak susu

Selain dilakukan pengujian MBRT, sampel susu juga dilakukan penghitungan terhadap jumlah bakteri (TPC). Berdasarkan hasil penghitungan jumlah bakteri (TPC), susu yang beredar di kota Yogyakarta selama bulan Januari hingga Maret 2017 secara berurutan masing-masing sebesar $1,1 \pm 0,5$ x $10^{4} ; 4,8 \pm 1,5 \times 10^{4} ;$ dan $9,7 \pm 5,1 \times 10^{4} \mathrm{cfu} /$ $\mathrm{ml}$, menunjukkan bahwa susu masih dalam 
keadaan aman dan layak untuk dikonsumsi. Rerata dari sampel susu yang diuji memiliki jumlah bakteri sebesar 5,2 $\pm 2,5 \times 10^{4} \mathrm{cfu} / \mathrm{ml}$ menunjukkan bahwa total bakteri yang ada di bawah standar yaitu kurang dari $1,0 \times 10^{6} \mathrm{cfu} /$ ml. SNI No. 01-3141.1-2011 menyebutkan bahwa batas maksimum cemaran mikroba pada susu segar adalah $1 \times 10^{6} \mathrm{cfu} / \mathrm{ml}$.

Rerata hasil TPC penelitian juga masih lebih rendah dibandingkan penelitian yang dilakukan oleh Cahyono et al. (2013), kualitas mikrobiologis susu segar di Kecamatan Krucil Kabupaten Probolinggo yang mempunyai ratarata TPC $7,4 \times 10^{5} \mathrm{cfu} / \mathrm{ml}$. Untuk meningkatkan mutu dari susu sapi perah supaya layak untuk dikonsumsi dapat dilakukan pengujian secara mikrobiologik yang meliputi jumlah dan jenis bakteri dalam susu sapi. Rendahnya jumlah TPC hasil penelitian ini kemungkinan disebabkan karena dilakukan pencucian putting sebelum pemerahan.

Apabila dilihat dari hasil penghitungan setiap bulannya, menunjukkan adanya variasi jumlah bakteri dalam setiap bulannya dan cenderung mengalami kenaikan. Sumber pencemaran maupun kontaminasi bakteri ini sebenarnya tidak hanya dimulai dari penjual saja akan tetapi dimulai dari peternak, proses pemerahan hingga susu tersebut sampai ke tangan konsumen. Keragaman dalam jumlah TPC susu segar disebabkan perbedaan dalam sanitasi peralatan, kandang dan pemerahan. Pada penelitian ini jumlah TPC yang bervariasi ini mungkin disebabkan oleh daerah buangan feses yang masih berdekatan dengan kandang, sehingga ketika dilakukan pemerahan mikroorganisme dapat masuk melalui debu yang dibawa oleh angin selama proses pemerahan maupun jual beli. Peralatan dapat menjadi sumber kontaminasi apabila tidak dibersihkan secara maksimal terutama bagian yang kontak langsung dengan susu. Proses pencemaran mikroba pada susu dimulai ketika susu diperah karena adanya mikroba yang tumbuh di sekitar ambing, sehingga saat pemerahan bakteri tersebut terbawa dengan susu.

Hal ini didukung oleh pendapat Gustiani
(2009) bahwa kontaminasi bakteri dimulai setelah susu keluar dari ambing. Susu akan segera terkontaminasi oleh mikroorganisme segera setelah keluar dari kelenjar susu oleh mikroorganisme yang berasal dari saluran putting. Millogo et al. (2010) menambahkan jumlah bakteri akan semakin meningkat pada jalur susu yang lebih panjang. Ketika dilakukan pengamatan secara langsung ditingkat peternak, pada saat pemerahan pertama-tama peternak mengelap ambing dan putting dengan menggunakan kain hangat, setelah itu puting akan diolesi dengan vaselin maupun minyak. Pemberian vaselin dimaksudkan agar susu mudah keluar serta cucuran pertama (fore milk) harus dibuang karena banyak mengandung mikroorganisme. Sanjaya et al. (2007) juga menambahkan bahwa sebelum memerah, tangan pemerah terlebih dulu dicuci dengan sabun dan disikat sampai bersih.

Sumber utama kontaminasi bakteri berasal dari udara, debu, peralatan yang kotor, petugas, dll, dengan demikian prosedur pembersihan dan sanitasi merupakan pengendali kualitas yang paling penting. Untuk dapat dikonsumsi, susu harus memenuhi persyaratan keamanan pangan karena susu mudah terkontaminasi mikroba (bakteri, kapang, dan khamir), baik patogen maupun nonpatogen dari lingkungan (peralatan pemerahan, operator, dan ternak), residu pestisida, logam berat dan aflatoksin dari pakan serta residu antibiotik saat pengobatan penyakit pada ternak. Kandungan mikroba yang tinggi menyebabkan susu cepat rusak (Djaafar dan Rahayu, 2007).

Pemeriksaan terkait kualitas mikrobiologis susu berdasarkan nilai TPC menjadi faktor penting, ketika susu segar akan diolah menjadi produk olahan lain untuk menghasilkan produk yang berkualitas baik dan memiliki daya simpan yang cukup lama. Tidak hanya itu pengujian mirobiologis ini menjadi parameter penting terhadap kelayakan susu sapi yang diterima oleh masyarakat sebagai bahan pangan yang ASUH (Budiyono, 2009). 


\section{KESIMPULAN}

Pengawasan kualitas pangan hewani dapat dilakukan secara rutin melalui pengujian kualitas susu sapi yang beredar di Kota Yogyakarta. Kualitas susu segar yang beredar di Kota Yogyakarta dalam keadaan baik, aman dan layak untuk dikonsumsi, karena telah sesuai dengan standar kualitas susu segar berdasarkan SNI No. 01-3141.1-2011, namun masih terdapat beberapa kekurangan yang perlu diperbaiki agar pengawasan peredaran susu segar lebih baik.

\section{UCAPAN TERIMA KASIH}

Kami ucapkan terima kasih kepada LPPM Universitas 'Aisyiyah Yogyakarta (UNISA) melalui skema Hibah Grant Internal UNISA yang telah mendanai penelitian ini sehingga penelitian ini dapat terlaksana dengan baik.

\section{DAFTAR PUSTAKA}

Agustina, T. 2016. Outlook Susu Komoditas Pertanian Subsektor Peternakan. ISSN: 1907-1507. Pusat Data dan Sistem Informasi Pertanian, Sekretariat Jenderal, Kementrian Pertanian, Jakarta. epublikasi.setjen.pertanian. go.id. Diakses pada tanggal 15 Agustus 2017.

Anjarsari, B. 2010. Pangan Hewani. Yogyakarta: Graha Ilmu

Badan Standardisasi Nasional. 2011. Standar nasional Indonesia susu segar. Bagian 1-Sapi SNI- 3141.1-2011. Badan Standardisasi Nasional, Jakarta. www. bsn.go.id. Diakses pada tanggal 2 Maret 2017.

Buckle, K. A., R. A. Edwards, G. H. Fleet, and M. Wooton. 2010. Ilmu Pangan, Diterjemahkan: H. Purnomo dan Adiono. UI Press, Jakarta.

Budiyanto, A. dan S. Usmiati. 2008. Pemerahan Susu secara Higienis
Menggunakan Alat Perah Sederhana. Seminar Nasional Teknologi Peternakan dan Veteriner.

Budiyono, H. 2009. Analisis Daya Simpan Produk Susu Pasteurisasi Berdasarkan Kualitas Bahan Baku Mutu Susu. Jurnal Paradigma 10 (2): 198-211

Cahyono, D., C. P. Masdiana dan E. S. Manik. 2013. Kajian Kualitas Mikrobiologis (Total Plate Count (TPC)), Enterobacteriaceae dan Staphylococcus aureus Susu Sapi Segar Di Kecamatan Krucil Kabupaten Probolinggo. Jurnal Ilmu dan Teknologi Hasil Ternak 8(1): $1-8$.

Diastari, I. G. A. F dan K. K. Agustina. 2013. Uji Organoleptik dan Tingkat Keasaman Susu Sapi Kemasan yang Dijual di Pasar Tradisional Kota Denpasar. Indonesia Medicus Veterinus 2(4) : $453-460$.

Djaafar, T. F. dan S. Rahayu. 2007. Cemaran Mikroba Pada Produk Pertanian, Penyakit yang Ditimbulkan dan Pencegahannya. Jurnal Litbang Pertanian Balai Pengkajian Teknologi Pertanian. Yogyakarta. 26(2) : 67-75.

Gustiani, E. 2009. Pengendalian cemaran mikroba pada bahan pangan asal ternak (daging dan susu) mulai dari peternakan sampai dihidangkan. Jurnal Litbang Pertanian 28 (3): 96-100.

Lingathurai, S., P. Vellathurai, S. E. Vendan and A. A. P. Anand. 2009. A comparative study on the microbiological and chemical composition of cow milk from different locations in Madurai, Tamil Nadu. Indian Journal of Science and Technology 2(2): 51-54.

Lukman, D. W., S M. udarwanto, A. W. Sanjaya, T. Purnawarman, H. Latif dan R. R. Soejoedono. 2009. Pemerahan dan Penanganan. Fakultas Kedokteran Hewan. Institut Pertanian Bogor, Bogor.

Millogo, V., K. S. Sjaunja, G. A. Ouedraogo dan S. Agenas. 2010. Raw milk 
hygiene at farms processing units and local markets in Burkina Faso. Journal of Food Control 21:1070-1074. www. elsevier.com/locate/foodcont.

Mirdhayati, I., H. Jully dan U. P. Khaidar. 2008. Mutu Susu Segar Di UPT Ruminansia Besar Dinas Peternakan Kabupaten Kampar Provinsi Riau. Jurnal Peternakan 5(1): 14 - 21.

Murti, T. W. 2010. Pasca Panen dan Industri Susu. Fakultas Peternakan Universitas Gadjah Mada, Yogyakarta.

Nababan, L. A., S. I Ketut dan B. N. S. Ida. 2014. Ketahanan Susu Segar pada Penyimpanan Suhu Ruang Ditinjau dari Uji Tingkat Keasaman, Didih, dan Waktu Reduktase. Indonesia Medicus Veterinus 3(4): 274-282.

Nandy, S. K. and K. V. Venkatesh. 2010. Application of methylene blue dye reduction test (MBRT) to determine growth and death rates of microorganisms. African Journal of Microbiology Research 4(1): 061-070

Saleh, E. 2004. Teknologi Pengolahan susu dan hasil ikutan ternak. Available at : http://library.usu.ac.id/download/fp/ ternak-eniza.pdf. Diakses hari minggu 24 Oktober 2016 pada pukul 19:25.

Sanam, A. B., I. B. N. Swacita dan K. K. Agustina. 2014. Ketahanan Susu Kambing Peranakan Ettawah PostThawing pada Penyimpanan Lemari Es Ditinjau dari Uji Didih dan Alkohol. J Veteriner 3(1) : 1-8.

Sanjaya, A. W., M. Sudarwanto, R. R. Soejoedono, T. Purnawarman, D. W. Lukman dan H. Latif. 2007. Higiene Pangan. Departemen Ilmu Penyakit Hewan dan Kesehatan Masyarakat Veteriner. FKH-IPB, Bogor.

Soeparno, R.A. Rihastuti, S. Indratiningsih dan Triatmojo. 2011. Dasar Teknologi Hasil Ternak. Gadjah Mada University Press. Yogyakarta

Suardana, I. W. dan I. B. N. Swacita. 2009.
Higiene Makanan. Kajian Teori Dan Prinsip Dasar. Fakultas Kedokteran Hewan. Universitas Udayana, Denpasar.

Sutrisna, D. Y., I. K. Suada dan I. P Sampurna. 2014. Kualitas Susu Kambing Selama Penyimpanan pada Suhu Ruang Berdasarkan Berat Jenis, Uji Didih, dan Kekentalan. J Veteriner 3(1) : 60-67.

Umar, R. dan Novita A. 2014. Derajat Keasaman Dan Angka Reduktase Susu Sapi Pasteurisasi Dengan Lama Penyimpanan Yang Berbeda. J Veteriner 8(1) : 43-46.

Usmiati, S dan Abubakar. 2009. Teknologi Pengolahan Susu. Balai Besar Penelitian dan Pengembangan Pascapanen Pertanian. Bogor.

Utami, K. B., L. E. Radiati dan P. Surjowardojo. 2014. Kajian kualitas susu sapi perah PFH (studi kasus pada anggota Koperasi Agro Niaga di Kecamatan Jabung Kabupaten Malang). JurnalJurnal Ilmu Peternakan 24(2): 58-66.

Waluyo, L. 2008. Metode Teknik Dasar Mikrobiologi. Universitas Muhammadiyah Malang, Malang.

Yusuf, R. 2010. Kandungan protein susu sapi perah friesian holstein akibat pemberian pakan yang mengandung tepung katu (sauropus androgynus (1.) merr) yang berbeda. Jurnal Teknologi Pertanian 6 (1): 1-6.

Zakaria, Y., M. Y. Helmy dan Y. Safara. 2011. Analisis Kualitas Susu Kambing Peranakan Etawah yang Disterilkan pada Suhu dan Waktu yang Berbeda. J Agripet 11(1): 29-31

Zurriyati Y., R. R. Noor dan R. R. A. Maheswari. 2011. Analisis molekuler genotipe kappa kasein ( $\kappa$ kasein) dan komposisi susu kambing Peranakan Etawah, Saanen dan Persilangannya. Bogor (ID): Jurnal Ilmu Ternak dan Veteriner 16(1) : 61-70. 